\title{
Clinical spectrum of ocular bobbing
}

\author{
JOHN O. SUSAC, WILLIAM F. HOYT, ROBERT B. DAROFF, AND \\ WILLIAM LAWRENCE
}

From Letterman General Hospital, San Francisco; University of California, San Francisco, California; Miami Veterans Administration Hospital; University of Miami School of Medicine, Miami, Florida, U.S.A.

SUMMARY Ocular bobbing is a distinctive movement disorder occurring in a variety of related forms herein classified as 'typical', 'monocular', and 'atypical'. 'Typical' ocular bobbing occurs in patients with paralysis of horizontal conjugate eye movements and consists of abrupt, spontaneous downward jerks of the eyes with a slow return to the mid position. The 'monocular' type reflects co-existing unilateral third nerve paresis in addition to the bobbing. The 'atypical' type includes either a variation unexplained by associated oculomotor palsy, or bobbing with intact spontaneous or reflex horizontal eye movements. The clinical spectrum of ocular bobbing, its varied causes, and its prognostic significance are exemplified in a report of nine cases.

Fisher (1961) called attention to a distinctive abnormality of eye movement which he descriptively termed 'ocular bobbing'. Later he expanded his clinical observations and included atypical cases (Fisher, 1964). Three additional reports have appeared subsequently (Daroff and Waldman, 1965; Hameroff, Garcia-Mullin, and Eckholdt, 1969; Nelson and Johnston, 1970). Our clinical observations of this ocular sign, like Fisher's (1964), have confirmed several related forms of bobbing, examples of which are described according to the following classification:

A. 'TYPICAL' BOBBING This form consists of abrupt, spontaneous, usually conjugate, downward jerks of both eyes followed by a slow return to the mid position. The eyes may remain in the eccentric (downward) position as long as 10 seconds before they again drift upward. The rate and rhythm are seldom predictable, and paralysis of horizontal (spontaneous and reflex) eye movements is an associated finding. Caloric stimulation occasionally produces an increase in the rate of bobbing. The patient may be comatose, obtunded, or fully conscious.

B. 'MONOCULAR' (OR PARETIC) BOBBING This occurs when a co-existing ocular motor palsy alters the appearance of 'typical' bobbing.

C. 'ATYPICAL' BOBBING This category consists of variations of 'typical' bobbing that cannot be explained by a superimposed palsy, as in B. In addition, ocular bobbing withoutco-existing paralysis of horizontal ocular movements warrants classification as an 'atypical' form.

CASE REPORTS

TYPICAL BOBBING

CASE 1 A 66 year old woman was admitted to the hospital with symptoms of vertigo, diplopia, and generalized weakness that progressed during the next three days. Examination on admission revealed a mildly confused, drowsy lady whose only neurological signs were dysarthria and horizontal gaze-evoked nystagmus to each side. Lumbar puncture revealed clear cerebrospinal fluid under normal pressure and containing no cells. Her condition seemed stable until suddenly, on the fourth hospital day, she lapsed into coma and showed the signs of decerebrate rigidity. She had typical ocular bobbing. Her eyes spontaneously jerked downward and returned slowly to the mid position either immediately, or after several seconds delay. A full range of eye movement was achieved during the rapid downward excursion. The eyes usually moved conjugately. The rate was unpredictable but it increased noticeably after caloric stimulation. She displayed no spontaneous or reflex horizontal eye movements. The pupillary size and response to light stimulation were normal. There were no signs of midline or limb myclonus.

On the eighth hospital day the patient died. Necropsy examination of the brain showed extensive haemorrhagic infarction of the right cerebellar hemisphere associated with diffuse oedema. Section of the brain-stem revealed no gross or microscopic evidence of haemorrhage or softening. 
CASE 2 A 44 year old woman was admitted to the hospital in coma. During the previous week she had complained of constant headache and perioral paraesthesias. On admission, she was decerebrate and displayed typical ocular bobbing. Ice water caloric stimulation produced no lateral ocular deviation, but did produce definite increase in the amplitude of the bobbing. By the second day the patient began responding to simple commands by nodding of her head or movement of a limb. She occasionally spoke a few words but was unable to move her eyes to either side on command, and voluntary upward gaze was limited to only $10^{\circ}$. Downward gaze was preserved. Ocular bobbing persisted and on the fourth hospital day she lapsed again into coma and died seven hours later. Necropsy examination of the brain revealed a ruptured aneurysm of the basilar artery with massive intrapontine haemorrhage. The midbrain and medulla were not involved.

These two cases depict the typical syndrome of ocular bobbing but only the second showed the commonly associated structural lesion of the pons. Three additional cases of 'typical' bobbing are summarized in the Table (cases 3 to 5).

\section{MONOCULAR BOBBING}

CASE 6 A 24 year old woman was admitted to the hospital in deep coma. The blood pressure was $240 / 140$ $\mathrm{mm} \mathrm{Hg}$ and the pulse rate 75 per minute. She had Cheyne-Stokes respiration and was decerebrate. The left pupil was dilated and non-reactive. There were no spontaneous or reflex horizontal eye movements. The right eye repeatedly bobbed downward, then slowly returned to the mid position. The left eye remained motionless. There was no sign of intorsion of the left globe during downward jerks of the fellow eye.

The cerebrospinal fluid was grossly bloody and the pressure increased. On the eighth hospital day the patient died. Neuropathological examination showed multiple small haemorrhages in the cerebral cortex and a massive intrapontine haemorrhage involving the basis pontis and the tegmentum bilaterally.

Clinically there was evidence of a third, and presumptive evidence of a fourth, nerve palsy on the left. This modified the typical picture of bobbing, producing 'monocular', or paretic, bobbing.

CASE 7 A 63 year old man who had had hypertension and diabetes was found in a confused state in his home and immediately admitted to the hospital. He was obtunded but able to respond to commands. He had left-sided hemiparesis and profound right-sided hemiplegia. The left pupil was dilated and unreactive. There was bilateral ptosis and paralysis of upward gaze. He could move his right eye downward but not his left. The latter only intorted during the attempt. Voluntary and reflex eye movements were absent in the horizontal plane. At irregular intervals, the right eye would abruptly descend as the left eye intorted. This modified or 'mono- cular' bobbing with intorsion jerks of the paretic eye persisted for the duration of his stay in the hospital (two months), after which he was moved to a nursing home.

Here a unilateral third nerve palsy modified the picture of typical bobbing, producing a syndrome of intorsion jerking of the left eye and downward bobbing of the right.

\section{ATYPICAL BOBBING}

CASE 8 A 27 year old man was admitted for the twentyfifth time to the hospital because of recurrent headaches and increasing lethargy. For a period of years he had numerous shunt procedures for hydrocephalus due to aqueductal stenosis. Bilateral postpapilloedema optic atrophy and paresis of upward gaze with pupillary areflexia were long-standing signs. At the time of admission he was obtunded and responded poorly to command. He had spontaneous downward bobbing and synchronous convergence of his eyes. The eyes would descend suddenly in a ' $V$ ' shaped pattern and then drift upward, diverging as they approached the horizontal plane. Voluntary or spontaneous horizontal eye movements were not present, but caloric and oculocephalic stimuli evoked tonic lateral deviation to the right and left. This ' $V$ ' type bobbing persisted even when his eyes were tonicall\$ deviated after caloric testing.

After revision of the malfunctioning shunt, he awoke and the 'atypical' bobbing stopped.

This case exemplifies 'atypical' bobbing because reflex horizontal eye movements were present an because convergence was superimposed on the $\overrightarrow{\hat{e}} \vec{\theta}$ downward movement of the eyes, resulting in ' $V$ ' bobbing.

CASE 9 A 69 year old diabetic, after operation for an abdominal aortic aneurysm, developed acute renal failure and required haemodialysis. After an infusion of hypertonic glucose and insulin to correct his hyperglycaemia, coma ensued. He did not respond to loud sounds and had no spontaneous movements of his left arm or leg. Pupillary size and reactions were normal. Spontaneous and reflex eye movements were present to the right but not to the left. Ocular bobbing occurred intermittently.

The patient's blood glucose was $24 \mathrm{mg} \%$. Coma persisted despite intravenous infusion of hypertonic glucose. All horizontal ocular movement stopped but the vertical bobbing movements continued until his death several hours later.

Gross and microscopic examination of the brain showed no lesion other than small cystic infarctions in the left cerebellar hemisphere and left caudate nucleus.

The bobbing here was 'atypical' initially in that conjugate horizontal eye movements were present $N$ in one direction. The typical pattern of bobbing evolved when horizontal eye movement ceased. 
Metabolic - that is, hypoglycaemic -encephalopathy rather than a structural lesion in the pons seemed the most reasonable explanation of the ocular bobbing in this patient.

\section{REVIEW OF LITERATURE}

Previous reports of ocular bobbing, in addition to our nine cases, are listed and characterized in the Table. The total number of patients is 25: 19 are 'typical', two 'monocular', and four 'atypical'.

\section{DISCUSSION}

Ocular bobbing is a distinctive, spontaneous eye movement that is readily distinguishable from down-

TABLE

SUMMARY OF REPORTED CASES*

\begin{tabular}{|c|c|c|c|c|c|}
\hline Author & $\begin{array}{l}\text { Caloric influence } \\
\text { on bobbing }\end{array}$ & $\begin{array}{l}\text { State of } \\
\text { consciousness }\end{array}$ & Outcome & Diagnosis & Remarks \\
\hline \multicolumn{6}{|l|}{$\begin{array}{l}\text { I. Typical ocular bobbing } \\
\text { Fisher (1964) }\end{array}$} \\
\hline Case 1 & None & Coma & Death & Pontine infarct & - \\
\hline Case 2 & None & Coma & Death & Pontine infarct & - \\
\hline Case 3 & None & Coma & Death & Pontine haemorrhage & Rate somewhat regular \\
\hline Case 8 & - & Awake & Death & - & Patient awake but akinetic \\
\hline $\begin{array}{l}\text { Daroff and Waldman (1965) } \\
\text { Hameroff et al (1969) }\end{array}$ & Increased & Coma & Death & Pontine glioma & Two year old child \\
\hline Case 1 & Increased & Coma & Death & $\begin{array}{l}\text { Post-traumatic contusions } \\
\text { of cortex, brain-stem, } \\
\text { cerebellum. }\end{array}$ & $\begin{array}{l}\text { Some rcflex horizontal eye. } \\
\text { movements present }\end{array}$ \\
\hline Case 2 & None & Coma & Death & Pontine haemorrhage & - \\
\hline Case 3 & - & Coma & Death & $\begin{array}{l}\text { No lesions. Presumed } \\
\text { brain-stem ischaemia }\end{array}$ & - \\
\hline Case 4 & Increased & Coma & Death & $\begin{array}{l}\text { Cerebellar haemorrhage } \\
\text { with brain-stem compression }\end{array}$ & - \\
\hline Case 5 & Increased & Coma & Recovered & - & $\begin{array}{l}\text { Bobbing occurred after a } \\
\text { cardiac arrest }\end{array}$ \\
\hline \multicolumn{6}{|l|}{ Nelson and Johnston (1970) } \\
\hline Case 1 & Increased & $\begin{array}{l}\text { Probable } \\
\text { coma }\end{array}$ & Death & Pontine haemorrhage & - \\
\hline Case 2 & Increased & Coma & Death & Pontine haemorrhage & - \\
\hline Case 3 & Increased & Coma & Death & Pontine haemorrhage & - \\
\hline Case 4 & Increased & Awake & Death & Pontine haemorrhage & $\begin{array}{l}\text { Patient conscious during } \\
\text { bobbing }\end{array}$ \\
\hline \multicolumn{6}{|l|}{ Susac et al (present report) } \\
\hline Case 1 & Increased & Coma & Death & $\begin{array}{l}\text { Haemorrhagic infarction } \\
\text { of cerebellum }\end{array}$ & $\pi^{\cdot} \cdot e^{\circ}$ \\
\hline Case 2 & Increased & Awake & Death & $\begin{array}{l}\text { Ruptured basilar artery } \\
\text { aneurysm with secondary } \\
\text { pontine haemorrhage }\end{array}$ & $\begin{array}{l}\text { Patient conscious during } \\
\text { bobbing }\end{array}$ \\
\hline Case 3 & - & Awake & Alive & $\begin{array}{l}\text { Presumed vertebral-basilar } \\
\text { insufficiency }\end{array}$ & Patient awake but akinetic \\
\hline Case 4 & None & $\begin{array}{l}\text { Awake- } \\
\text { coma }\end{array}$ & $\begin{array}{l}\text { Death } \\
\text { (pneumonia) }\end{array}$ & Pontine haemorrhage & $\begin{array}{l}\text { Bobbing present when patient } \\
\text { was awake and persisted } \\
\text { during later coma }\end{array}$ \\
\hline Case 5 & None & Coma & Death & 一 & Diazepam inhibited bobbing \\
\hline \multicolumn{6}{|c|}{$\begin{array}{l}\text { II. Monocular (or paretic) bobbing } \\
\text { Susac et al (present report) }\end{array}$} \\
\hline Case 6 & None & Coma & Death & $\begin{array}{l}\text { Pontine haemorrhage } \\
\text { Hypertensive } \\
\text { encephalopathy }\end{array}$ & $\begin{array}{l}\text { Monocular bobbing due to } \\
\text { unilateral } 3 \text { rd and } 4 \text { th nerve } \\
\text { paralysis }\end{array}$ \\
\hline Case 7 & None & Awake & Alive & Suspected pontine infarction & $\begin{array}{l}\text { Monocular bobbing due to } \\
\text { unilateral } 3 \text { rd nerve paralysis }\end{array}$ \\
\hline \multicolumn{6}{|l|}{$\begin{array}{l}\text { III. Atypical ocular bobbing } \dagger \\
\text { Fisher (1964) }\end{array}$} \\
\hline Case 4 & 一 & Coma & Death & Cerebellar haemorrhage & $\begin{array}{l}\text { Retention of reflex horizontal } \\
\text { eye movements }\end{array}$ \\
\hline $\begin{array}{l}\text { Case } 7 \\
\text { Susac et al (present report) }\end{array}$ & - & Coma & Death & - & Same as above \\
\hline $\begin{array}{l}\text { Case } 8 \\
\text { Case } 9\end{array}$ & $\begin{array}{l}\text { None } \\
\text { None }\end{array}$ & $\begin{array}{l}\text { Semi-coma } \\
\text { Coma }\end{array}$ & $\begin{array}{l}\text { Recovered } \\
\text { Death }\end{array}$ & $\begin{array}{l}\text { Obstructive hydrocephalus } \\
\text { Metabolic encephalopathy }\end{array}$ & $\begin{array}{l}\text { Same as above. ' } V \text { ' bobbing } \\
\text { Retention of reflex horizontal } \\
\text { eye movements }\end{array}$ \\
\hline
\end{tabular}


beating nystagmus (Cogan, 1968), and ocular myoclonus (Daroff and Waldman, 1965). The initial fast phase followed, after occasional delays, by a slow return is the reverse of the slow-fast sequence of jerk nystagmus. Eye movements in ocular myoclonus may, like bobbing, beat downward but are regular in rate, equal in speed (pendular), and synchronous with movements of other midline structures. Yap, Mayo, and Barron's (1968) recent misuse of Fisher's term 'ocular bobbing' to describe myoclonus has produced predictable confusion (Solomon and Chutorian, 1968).

The spectrum of ocular bobbing described in this report illustrates the phenomenological variability of the sign, the differing clinical settings in which it is encountered, and the diversity of diseases with which it may be associated. A comatose state is the rule but five of the nineteen reported 'typical' cases were awake while bobbing. Previous reports of this ocular sign have stressed the ominous prognosis and preterminal condition of the patient. Our experience is basically confirmatory. Three of our patients survived but two with significant fixed neurological deficits. The third (case 5) resumed his previous clinical status after a shunting procedure relieved obstructive hydrocephalus.

Although the usual neuropathological substrate of 'typical' ocular bobbing is an extensive intrapontine haemorrhage, infarction or tumour, two patients within the total series had pontine compression from a cerebellar haematoma. Predictably, 'atypical' ocular bobbing - so defined because of horizontal eye movement preservation-does not result from intrinsic pontine lesions. Cerebellar haemorrhage, obstructive hydrocephalus, and metabolic encephalopathy have been causal in this 'atypical' variety.

With Dr. Bernard Slatt (University of Toronto) one of us (W.F.H.) examined a 57 year old hypertensive woman who suddenly developed left-sided hemisensory loss (face, arm, and leg), transient paresis of the left leg, bilateral pontine gaze palsies, and marked dysarthria. Six months later she complained of oscillopsia and examination revealed a constant gross vertical downbeating of both eyes between the mid and full downward position of gaze. The rate was approximately 1 to 2 beats per second and regular. She had no evidence of myoclonus of the palate, or other bulbar musculature, and she was fully alert and communicative despite her dysarthria. Whereas her eye movement disorder resembled 'typical' bobbing, its delayed development, rhythmicity, and rapid rate better typified 'ocular myorhythmia' (Jung and Kornhuber, 1964).

Irregular spasms of conjugate downward gaze occur in various metabolic encephalopathies, usually in association with decerebrate signs (Daroff and Hoyt, 1970); in patients with medial thalamic apoplexy (Fisher, 1967); or transiently in otherwise healthy neonates (Walsh and Hoyt, 1969). Spastic downward vertical deviation also occurs in young children with intermittent hydrocephalus from posterior third ventricle tumours; in most instances an associated paresis of upward gaze is present. Downward rather than horizontal eye movements may be evoked by vestibular stimulation in rare instances (Fisher, 1964). The relation of these various types of downward gaze spasms and movements to ocular bobbing may be significant but is undetermined at present.

The whole issue of the pathophysiology of ocular bobbing is obscure. Fisher (1964) postulated that it represents normal roving movements of the eyes in patients who have lost all ability to generate lateral eye movements. Daroff and Waldman (1965) questioned the applicability of 'normal roving' movements and suggested instead that the sign was generated within the medulla and was triggered by either cortical discharges, vestibular influences, or both. This conceptualization was based partly ono experimental evidence (Spiegel, 1933) that unilatera $\overline{\mathrm{Q}}$ cortical stimulation preferentially evoked eye move ments in the vertical plane only after bilaterad vestibular injury. Recently, there was confirmations of this observation in laboratory animals after removal of the vestibular nuclear complex (Mann? and Giretti, 1969). We know of no additional experis mental data that supports or refutes the proffere $\mathbb{A}$ speculations concerning the mechanism of ocular bobbing.

\section{REFERENCES}

Cogan, D. G. (1968). Down-beat nystagmus. Arch. Ophthal., 80, 757-768.

Daroff, R. B., and Waldman, A. L. (1965). Ocular bobbing. J. Neurol. Neurosurg. Psychiat., 28, 375-377.

Daroff, R. B., and Hoyt, W. F. (1970). Supranuclear disorders of ocular control systems in man. Clinical, anatomical and physiological correlations. In: The Control of Eye Movements, edited by P. Bach-yRita and C. C. Collins. Academic Press: New York.

Fisher, C. M. (1961). In: Pathogenesis and Treatment of Cerebrovascular Disease. A symposium edited by W. S. Fields. Thomas, Springfield, Illinois.

Fisher, C. M. (1964). Ocular bobbing. Arch. Neurol. (Chic.), 11, 543-546.

Fisher, C. M. (1967). Some neuro-ophthalmological observations. J. Neurol. Neurosurg. Psychiat., 30, 383-392.

Hameroff, S. B., Garcia-Mullin, R., and Eckholdt, J. (1969). Ocular bobbing. Arch. Ophthal., 82, 774-780.

Jung, R., and Kornhuber, H. H. (1964). Results of electronystagmography in man: The value of optokinetic, vestibular, and spontaneous nystagmus for neurologic diagnosis and research. In: The Oculomotor System, edited by M. B. Bender, pp. 428-482, Harper and Row: New York. 
Manni, E., and Giretti, M. L. (1969). Role of the vestibular nuclei in the cerebral eye nystagmus. Europ. Neurol., 2, 65-75.

Nelson, J. R., and Johnston, C. H. (1970). Ocular bobbing. Arch. Neurol. (Chic.), 22, 348-356.

Solomon, G. E., and Chutorian, A. M. (1968). Opsoclonus and occult neuroblastoma. New Engl. J. Med., 279, 475-477.
Spiegel, E. A. (1933). Role of vestibular nuclei in the cortical innervation of the eye muscles. Arch. Neurol. Psychiat. (Chic.), 29, 1084-1097.

Walsh, F. B., and Hoyt, W. F. (1969). Clinical NeuroOphthalmology, p. 230, 3rd edited by Williams and Wilkins Co.: Baltimore.

Yap, C. B., Mayo, C., and Barron, K. (1968). 'Ocular bobbing' in palatal myoclonus. Arch. Neurol. (Chic.), 18, 304-310. 